\title{
PENGARUH MODEL PEMBELAJARAN KOOPERATIF TIPE TAI DAN PROBLEM BASED LEARNING (PBL) TERHADAP PEMAHAMAN KONSEP BANGUN RUANG SISWA
}

\author{
Lia Budi Tristanti \\ STKIP PGRI Jombang \\ Email: btlia@rocketmail.com
}

\begin{abstract}
The objective of the research is to describe whether there is a difference of students' understanding of mathematical concepts using cooperative learning model of TAI type and Problem Based Learning (PBL) and show the cause of the difference. This study included experimental research with randomized control group design pretest posttest design. The result of the research shows that (1) the understanding of students 'mathematical concepts with cooperative learning model of TAI type is not significantly different from the understanding of students' mathematics concept with PBL learning model; (2) the understanding of students 'mathematical concept with cooperative learning model of TAI type is not significantly different from the students' with conventional learning model, (3) understanding of student math concept with PBL learning model is significantly different with understanding of student math concept with conventional learning model. So that there is effect of cooperative learning model of TAI type and problem based learning (PBL) to the students' math concept.
\end{abstract}

Keywords: PBL, TAI, understanding concept

\section{PENDAHULUAN}

Pembelajaran matematika menekankan pada kemampuan siswa untuk berpikir (National Council of Teachers of Mathematics (NCTM), 2000). Sedangkan berdasarkan KI 3 dalam kurikulum 2013, kemampuan yang harus dimiliki siswa setelah belajar matematika adalah memahami pengetahuan dan memiliki sikap ingin tahu. Siswa harus tertantang dan terdorong untuk mengembangkan kemampuan berpikirnya melalui bertanya, berdiskusi ide-ide, strategi, dan solusi dalam menyelesaikan masalah. Tujuan pembelajaran matematika menjelaskan bahwa pelajaran matematika bertujuan agar siswa memahami konsep matematika. Sehingga, siswa diharapkan tidak hanya sekedar tahu (knowing) dan hafal (memorizing) konsep-konsep matematika, namun juga harus mengerti dan memahami (to understand) konsep matematika tersebut serta menghubungkan keterkaitan antara satu konsep dengan konsep lain.

Ciri pembelajaran matematika menurut pandangan konstruktivisme yaitu Siswa terlibat aktif dalam belajar, informasi baru harus dikaitkan dengan informasi lain sehingga menyatu dengan skemata yang dimiliki siswa agar pemahaman terhadap informasi (materi) kompleks terjadi, dan pembelajaran berorientasi pada investigasi dan penemuan yang pada dasarnya adalah pemecahan masalah (Hudojo, 2001). Pembelajaran matematika adalah suatu upaya membantu siswa untuk mengkonstruksi (membangun) konsepkonsep atau prinsip-prinsip matematika dengan kemampuannya sendiri melalui proses internalisasi sehingga konsep 
atau prinsip itu terbangun kembali (Ratumanan, 2002: 3). Transformasi informasi yang diperoleh menjadi konsep atau prinsip baru. Transformasi tersebut dapat mudah terjadi bila terjadi pemahaman karena terbentuknya skemata dalam benak siswa. Dengan demikian pembelajaran matematika adalah suatu proses membangun pemahaman siswa. Sehingga dapat disimpulkan bahwa pembelajaran matematika adalah sebagai upaya untuk membangkitkan minat siswa dalam belajar dan lebih menekankan pada bagaimana guru mendorong siswa untuk belajar, bukan pada apa yang dipelajari siswa. Pembelajaran matematika adalah untuk membantu siswa membangun konsep-konsep atau prinsip-prinsip matematika dengan kemampuannya sendiri melalui proses internalisasi sehingga konsep atau prinsip itu terbangun kembali.

Pendidik dapat menggunakan model pembelajaran kooperatif mewujudkan tujuan pembelajaran matematika. Cooperative Learning adalah suatu strategi belajar mengajar yang menekankan pada sikap atau perilaku bersama dalam bekerja atau membantu diantara sesama dalam struktur kerja sama yang teratur dalam kelompok, yang terdiri dari dua orang atau lebih. Pembelajaran kooperatif merupakan strategi belajar dengan sejumlah siswa sebagai anggota kelompok kecil yang tingkat kemampuannya berbeda. Dalam menyelesaikan tugas kelompoknya, setiap siswa anggota kelompok harus saling bekerja sama dan saling membantu untuk memahami materi pelajaran. Pembelajaran matematika lebih efektif dengan menggunakan kooperatif (Gupta dan Jain, 2014; Tarim dan Akdeniz, 2008; Reid, 1992; Xin, 1996).
Terdapat beberapa tipe model pembelajaran kooperatif, salah satunya adalah model pembelajaran kooperatif tipe Team Assisted Individualization (TAI). Model pembelajaran kooperatif tipe TAI merupakan model pembelajaran yang inovatif yang dapat memberikan kondisi belajar aktif kepada siswa (Slavin, 1994; Vaughan, 2002, Hariyati, Mardiyana dan Usodo, 2013; Asriningsih, Renda, dan Wibawa, 2014; Tinungki, 2015). TAI memiliki prosedur sederhana yang mudah diterapkan (Tarim, dan Akdeniz, 2008). Selain itu, instruksi TAI dapat disesuaikan dengan kebutuhan individual siswa. Ciri khas pada model pembelajaran TAI ini adalah setiap peserta didik secara individual belajar materi pembelajaran yang sudah dipersiapkan oleh pendidik. Hasil belajar individual dibawa ke kelompokkelompok untuk didiskusikan dan saling dibahas oleh anggota kelompok, dan semua anggota kelompok bertanggung jawab atas keseluruhan jawaban sebagai tanggung jawab bersama.

Model pembelajaran kooperatif tipe TAI dapat diaplikasikan dalam pembelajaran matematika karena salah satu ciri khusus pembelajaran matematika adalah memecahkan berbagai masalah matematika, baik masalah yang terhubung dengan kehidupan nyata atau tidak. Model pembelajaran kooperatif dapat memacu semangat peserta didik untuk saling membantu dalam memecahkan masalah matematika (Ramlan, 2013 dan Tristanti dan Rakhmawati, 2017). Hasil penelitian (Hariyati, Mardiyana dan Usodo, 2013) menyatakan model pembelajaran kooperatif tipe TAI memberikan prestasi belajar matematika lebih baik dibandingkan model pembelajaran $\mathrm{PBL}$ dan konvensional. Slavin (1983) menyatakan bahwa TAI sesuai untuk kelas matematika. 
Sedangkan Tarim dan Akdeniz, (2008) juga menyatakan TAI memiliki pengaruh yang lebih signifikan daripada metode STAD terhadap prestasi akademik siswa dalam matematika. TAI dapat mengembangkan nilai karakter tanggung jawab siswa dalam pembelajaran matematika (Pasani \& Basil, 2014). Hasil penelitian Johnson,
Johnson, \& Stanne, (2000) menunjukkan TAI memiliki efek positif pada prestasi akademik dalam matematika. Tabel 1 menunjukkan langkah Model Pembelajaran Kooperatif tipe TAI.

Tabel 1 Langkah Model Pembelajaran Kooperatif tipe TAI

\begin{tabular}{|c|c|}
\hline Tahap & Tindakan Guru \\
\hline $\begin{array}{l}\text { Fase 1 } \\
\text { Menyampaikan tujuan dan } \\
\text { motivasi belajar }\end{array}$ & $\begin{array}{l}\text { Guru menyampaikan semua tujuan pembelajaran } \\
\text { dan motivasi siswa untuk belajar. }\end{array}$ \\
\hline $\begin{array}{l}\text { Fase } 2 \\
\text { Menyajikan informasi }\end{array}$ & $\begin{array}{l}\text { Guru menyampaikan informasi kepada siswa } \\
\text { dengan jalan demostrasi atau melalui bahan } \\
\text { bacaan. }\end{array}$ \\
\hline $\begin{array}{l}\text { Fase } 3 \\
\text { Mengorganisasikan peserta didik } \\
\text { ke dalam kelompok-kelompok } \\
\text { belajar }\end{array}$ & $\begin{array}{l}\text { Guru menjelaskan kepada siswa cara membentuk } \\
\text { kelompok belajar dan membantu setiap kelompok } \\
\text { agar melakukan transisi secara efisien. }\end{array}$ \\
\hline Placement Test (Tes Penempatan) & $\begin{array}{l}\text { Guru memberikan tes penempatan untuk } \\
\text { membentuk kelompok }\end{array}$ \\
\hline Teams (Team) & $\begin{array}{l}\text { Guru membentuk kelas menjadi kelompok- } \\
\text { kelompok kecil yang terdiri 4-5 siswa yang } \\
\text { heterogen berdasarkan hasil tes penempatan }\end{array}$ \\
\hline $\begin{array}{l}\text { Fase } 4 \\
\text { Membimbing kelompok bekerja } \\
\text { dan belajar }\end{array}$ & Guru membimbing kelompok-kelompok belajar \\
\hline Teaching Group (Mengajar grup) & $\begin{array}{l}\text { Guru memberikan sekilas mengenai materi } \\
\text { sedangkan sebagian besar materi dipebelajari } \\
\text { siswa secara individual dalam kelompok }\end{array}$ \\
\hline Student Creative (Siswa Kreatif) & $\begin{array}{l}\text { Guru menjelaskan dan membangun presepsi siswa } \\
\text { bahwa keberhasilan individu ditentukan oleh } \\
\text { keberhasilan kelompok }\end{array}$ \\
\hline $\begin{array}{l}\text { Tahap } 5 \\
\text { Team Study (Belajar Kelompok) }\end{array}$ & $\begin{array}{l}\text { Siswa belajar bersama dengan mengerjakan } \\
\text { Lembar Kerja Siswa yang diberikan. Guru sesekali } \\
\text { membatu peserta didik yang memiliki peran } \\
\text { sebagai tutor sebaya dalam kelompok jika } \\
\text { menemui kesulitan. }\end{array}$ \\
\hline $\begin{array}{l}\text { Fase } 5 \\
\text { Evaluasi }\end{array}$ & $\begin{array}{l}\text { Guru mengevaluasi hasil belajar tentang materi } \\
\text { yang telah dipelajari atau masing-masing } \\
\text { kelompok mempresentasikan hasil kerjanya. }\end{array}$ \\
\hline Fact Test (Tes Fakta) & $\begin{array}{l}\text { Guru memberikan tes-tes kecil kepada setiap } \\
\text { individu untuk mengetahui sejauh mana } \\
\text { kemampuan yang dimiliki mereka. }\end{array}$ \\
\hline
\end{tabular}




\begin{tabular}{|l|l|}
\hline $\begin{array}{l}\text { Fase 6 } \\
\text { Memberikan penghargaan }\end{array}$ & $\begin{array}{l}\text { Guru menetukan cara untuk menghargai upaya dan } \\
\text { hasil belajar individu ataupun kelompok. }\end{array}$ \\
\hline $\begin{array}{l}\text { Team Score and Team Recognition } \\
\text { (Skor Tim dan Pengakuan Tim) }\end{array}$ & $\begin{array}{l}\text { Guru memberikan skor pada hasil kerja kelompok } \\
\text { dan memberikan penghargaan untuk kelompok } \\
\text { yang mendapatkan skor terbaik. }\end{array}$ \\
\hline
\end{tabular}

Pendidik juga dapat menggunakan Problem Based Learning (PBL) dalam mewujudkan tujuan pembelajaran matematika. Problem Based Learning (PBL) merupakan model pembelajaran yang menghadapkan siswa pada masalah autentik sehingga siswa diharapkan mengkonstruk pengetahuan dan pemahaman secara mandiri. Menurut Shoimin (2014) model pembelajaran Problem Based Learning (PBL) diberikan kepada siswa untuk melatih kemampuan memecahkan suatu masalah pada kehidupan nyata. Ciri utama dari model pembelajaran Problem Based Learning (PBL) diantaranya adalah pegajuan masalah atau pertanyaan, keterkaitan dengan disiplin ilmu yang lain, penyelidikan yang autentik, menghasilkan dan memamerkan hasil karya, dan kolaborasi. Model Problem Based Learning (PBL) dapat mengembangkan pemikiran kritis dan kreatif peserta didik (Kurniasih \& Sani, 2016: 49). Tabel 2 menunjukkan langkah Problem Based Learning (PBL).

Tabel 2 Langkah Problem Based Learning (PBL)

\begin{tabular}{|c|c|}
\hline Tahap & Tingkah Laku Pendidik \\
\hline $\begin{array}{c}\text { Tahap 1 } \\
\text { Memusatkan orientasi } \\
\text { peserta didik pada masalah }\end{array}$ & $\begin{array}{c}\text { Pendidik menjelaskan tujuan pembelajaran, menjelaskan } \\
\text { logistik yang dibutuhkan,dan memotivasi peserta didik } \\
\text { untuk terlibat aktif dalam pemecahan masalah. }\end{array}$ \\
\hline $\begin{array}{c}\text { Tahap 2 } \\
\text { Mengorganisir peserta } \\
\text { didik untuk belajar }\end{array}$ & $\begin{array}{c}\text { Pendidik membantu peserta didik mendefinisikan dan } \\
\text { mengorganisasikan tugas belajar yang berhubungan dengan } \\
\text { masalah tersebut. }\end{array}$ \\
\hline $\begin{array}{c}\text { Tahap 3 } \\
\text { Membimbing penyelidikan } \\
\text { individual }\end{array}$ & $\begin{array}{c}\text { Pendidik mendorong peserta didik untuk mengumpulkan } \\
\text { informasi yang sesuai dengan masalah. }\end{array}$ \\
\hline $\begin{array}{c}\text { Tahap 4 } \\
\text { Mengembangkan dan }\end{array}$ & $\begin{array}{c}\text { Pendidik membentuk kelompok belajar kecil untuk } \\
\text { membantu peserta didik mengembangkan hasil karya, dan } \\
\text { peserta didik menyajikan hasil karya berupa penyelesaian } \\
\text { permasalahannya di depan kelas. }\end{array}$ \\
\hline $\begin{array}{c}\text { Tahap 5 } \\
\text { Menganalisis dan } \\
\text { mengevaluasi proses } \\
\text { pemecahan masalah }\end{array}$ & $\begin{array}{c}\text { Pendidik memberikan klarifikasi jawaban terhadap hasil } \\
\text { karya yang telah disajikan dilihat dari penyelidikan dan } \\
\text { proses-proses pengerjaan yang digunakan peserta didik. }\end{array}$ \\
\hline
\end{tabular}

Kajian teori menunjukkan bahwa aplikasi model pembelajaran kooperatif tipe TAI dan PBL memberikan efek yang positif dalam pembelajaran matematika, oleh karena itu dalam penelitian ini akan melihat perbedaan pemahaman siswa terhadap konsep matematika yang menggunakan model pembelajaran kooperatif tipe TAI dan Problem Based Learning (PBL) dan menunjukkan penyebab perbedaan tersebut. 


\section{METODE PENELITIAN}

Penelitian ini termasuk penelitian eksperimen dengan desain randomized control group pretest posttest design. Dalam desain ini terdapat tiga kelompok, dua sebagai kelompok eksperimen dan satu sebagai kelompok kontrol. Pada peneliti ini kelompok eksperimen yang pertama adalah kelompok yang menggunakan model pembelajaran kooperatif tipe Team Assisted Individualization (TAI), dan kelompok eksperimen yang kedua adalah kelompok yang menggunakan model pembelajaran Problem Based Learning (PBL), sedangkan kelompok kontrol adalah kelompok yang menggunakan konvensional.

Tabel 3 Gambaran Rancangan Penelitian

\begin{tabular}{|c|c|c|c|}
\hline Kelompok & Pretest & Perlakuan & Postest \\
\hline$E_{1}$ & $T_{1}$ & $X_{1}$ & $T_{2}$ \\
\hline$E_{2}$ & $T_{1}$ & $X_{2}$ & $T_{2}$ \\
\hline$K$ & $T_{1}$ & - & $T_{2}$ \\
\hline
\end{tabular}

Keterangan :

$E_{1}$ : Kelompok yang pembelajarannya menggunakan model pembelajaran kooperatif tipe Team Assisted Individualization (TAI).

$E_{2}$ : Kelompok yang pembelajarannya menggunakan model pembelajaran Problem Based Learning (PBL).

$K$ : Kelompok yang pembelajarannya menggunakan pembelajaran konvensional.

$X_{1}$ : Model pembelajaran kooperatif tipe Team Assisted Individualization (TAI).

$X_{2}$ : Model pembelajaran Problem Based Learning (PBL).

$T_{1}$ : Nilai hasil belajar matematika peserta didik sebelum mendapat perlakuan.

$T_{2}$ : Nilai hasil belajar matematika peserta didik sesudah mendapat perlakuan.

Penelitian ini dilaksanakan di kelas $\mathrm{X}$ MA Ismailiyah Jombang semester genap tahun pelajaran 2016/2017. Populasi penelitian adalah seluruh siswa kelas $\mathrm{X}$ pada sekolah tersebut. Terdapat 7 kelas pada tingkat
X. Dalam penelitian ini menggunakan sampling acak sederhana (simple random sampling) dalam menentukan sampel penelitian. Sampel yang digunakan adalah peserta didik di kelas. Penentuan sampel dilakukan dengan cara pengundian kelas, hal ini disebabkan karena beberapa faktor yaitu tidak ada ijin dari pihak sekolah untuk mengundi peserta didik satu persatu, keterbatasan waktu, dan menyebabkan kegaduhan sehingga dapat mengganggu peserta didik yang lain. Maka peneliti menyediakan tujuh gulungan kertas dan melakukan penentuan sampel dengan pengundian peserta didik didalam kelas. Pada pengundian disepakati bahwa pengambilan pertama dijadikan sebagai kelas eksperimen satu, pengambilan kedua dijadikan sebagai kelas eksperimen dua, dan pengambilan ketiga dijadikan sebagai kelas kontrol.

Selanjutnya siswa dikelompokkan menjadi tiga bagian secara acak sebagai sampel. Satu kelompok sebagai kelompok eksperimen yang pertama, satu kelompok sebagai kelompok eksperimen yang kedua dan satu kelompok kontrol adalah kelompok yang menggunakan pembelajaran konvensional. 
Intrumen penelitian ini berupa tes, ketiga kelompok penelitian diberikan tes yang sama. Tes tersebut digunakan untuk mengumpulkan data pemahaman siswa terhadap konsep matematika. Hasil ketiga tes hasil belajar tersebut akan dibandingkan (diuji perbedaannya). Sebelum data hasil belajar diuji perbedaannya, terlebih dahulu dilakukan uji kenormalan data dan kehomogenan data. Sedangkan untuk mengetahui perbedaan hasil belajar matematika antara siswa yang menggunakan model pembelajaran kooperatif tipe Team Assisted Individualization (TAI), Problem Based Learning (PBL), dan pembelajaran konvensional, digunakan uji varian satu arah (one way anova). Berikut adalah hipotesis penelitian:

$H_{0}$ : Tidak ada perbedaan hasil belajar matematika peserta didik yang menggunakan model pembelajaran kooperatif tipe Team Assisted Individualization (TAI), Problem Based Learning (PBL), dan konvensional.

$H_{1}$ : Ada perbedaan hasil belajar matematika peserta didik yang menggunakan model pembelajaran kooperatif tipe Team Assisted Individualization (TAI), Problem Based Learning (PBL), dan konvensional.

Ketika $H_{0}$ ditolak, maka dilakukan uji lanjut anova dengan teknik tukey untuk melihat model pembelajaran manakah yang paling berbeda secara signifikan. Berikut hipotesisnya:

1. $H_{0}$ : tidak ada perbedaan hasil belajar matematika siswa yang menggunakan model pembelajaran kooperatif tipe Team Assisted

Individualization (TAI) dan

Problem Based Learning (PBL)

$H_{1}$ : ada perbedaan hasil belajar matematika siswa yang menggunakan model pembelajaran kooperatif tipe Team Assisted Individualization (TAI) dan Problem Based Learning (PBL)

2. $H_{0}$ : tidak ada perbedaan hasil belajar matematika siswa yang menggunakan model pembelajaran kooperatif tipe Team Assisted Individualization (TAI) dan konvensional

$H_{1}$ : ada perbedaan hasil belajar matematika siswa yang menggunakan model pembelajaran kooperatif tipe Team Assisted Individualization (TAI) dan konvensional

3. $H_{0}$ : tidak ada perbedaan hasil belajar matematika siswa yang menggunakan Problem Based Learning (PBL) dan konvensional

$H_{1}$ : ada perbedaan hasil belajar matematika siswa yang menggunakan Problem Based Learning (PBL) dan konvensional

\section{HASIL PENELITIAN DAN PEMBAHASAN}

Tabel 4 menunjukkan hasil penelitian terkait data pemahaman konsep matematika siswa MA Ismailiyah Jombang. 
ISSN 2089-8703 (Print) Vol. 6, No. 3 (2017)

ISSN 2442-5419 (Online)

Tabel 4 Data Pemahaman Konsep Matematika

\begin{tabular}{|c|c|c|c|c|c|c|}
\hline \multirow{2}{*}{ No } & \multicolumn{2}{|c|}{ Kelompok E1 } & \multicolumn{2}{c|}{ Kelompok E2 } & \multicolumn{2}{c|}{ Kelompok K } \\
\cline { 2 - 7 } & Pre test & Post Test & Pre Test & Post test & Pre test & Post test \\
\hline 1 & 65 & 95 & 70 & 85 & 75 & 80 \\
\hline 2 & 70 & 85 & 65 & 85 & 65 & 80 \\
\hline 3 & 60 & 80 & 60 & 95 & 65 & 80 \\
\hline 4 & 60 & 90 & 65 & 85 & 65 & 85 \\
\hline 5 & 70 & 95 & 70 & 90 & 75 & 80 \\
\hline 6 & 65 & 85 & 70 & 95 & 70 & 85 \\
\hline 7 & 60 & 85 & 60 & 85 & 65 & 80 \\
\hline 8 & 65 & 80 & 60 & 90 & 60 & 80 \\
\hline 9 & 70 & 80 & 70 & 85 & 65 & 85 \\
\hline 10 & 60 & 85 & 65 & 90 & 70 & 85 \\
\hline 11 & 60 & 85 & 60 & 85 & 70 & 80 \\
\hline 12 & 70 & 95 & 75 & 85 & 65 & 85 \\
\hline 13 & 65 & 85 & 70 & 90 & 60 & 80 \\
\hline 14 & 60 & 85 & 75 & 90 & 65 & 85 \\
\hline 15 & 60 & 85 & 65 & 85 & 70 & 90 \\
\hline
\end{tabular}

Sebelum data pemahaman konsep siswa diuji perbedaannya, terlebih dahulu dilakukan uji kenormalan data dan kehomogenan data. Tabel 5 menunjukkan hasil uji normalitas data hasil belajar matematika.

Tabel 5 Hasil Uji Normalitas Data Pemahaman Konsep Matematika

\begin{tabular}{|c|c|c|}
\hline Kelompok & Test & Nilai Sig \\
\hline \multirow[t]{2}{*}{$E_{1}$} & Pretest & 0,160 \\
\hline & Posttest & 0,069 \\
\hline \multirow[t]{2}{*}{$E_{2}$} & Pretest & 0,556 \\
\hline & Posttest & 0,083 \\
\hline \multirow[t]{2}{*}{$K$} & Pretest & 0,225 \\
\hline & Posttest & 0,075 \\
\hline
\end{tabular}

Hasil uji normalitas data pemahaman konsep matematika yang disajikan pada Tabel 5 menunjukkan setiap nilai sig > 0,05 . Hal tersebut berarti data hasil belajar matematika disetiap kelompok berdistibusi normal.

Tabel 6 Hasil uji homogenitas data pemahaman konsep matematika

\begin{tabular}{|c|c|}
\hline Test & Nilai Sig \\
\hline Pretest & 0,619 \\
\hline Posttest & 0,366 \\
\hline
\end{tabular}


Hasil uji homogenitas data pemahaman konsep matematika yang disajikan pada Tabel 6 menunjukkan setiap nilai sig > 0,05. Hal tersebut berarti data hasil pemahaman konsep matematika baik pada pretest maupun posttest memiliki varians homogens.

Hasil analisis data hasil belajar siswa pada Tabel 7 menunjukkan setiap nilai sig $<0,05$, sehingga $H_{0}$ ditolaknya, dapat disimpulkan ada perbedaan ratarata pemahaman konsep matematika siswa yang menggunakan model pembelajaran kooperatif tipe Team Assisted Individualization (TAI), Problem Based Learning (PBL), dan konvensional.

Dari uji hipotesis yang menunjukkan $H_{0}$ ditolak, maka perlu dilakukan uji lanjut untuk melihat perbedaan yang terjadi pada setiap kelompok. Uji lanjut yang digunakan dalam penelitian ini adalah uji Post Hoc Tests.

Tabel 7 Out Put ANOVA

Pemahaman_Konsep_Matematika

\begin{tabular}{|l|r|r|r|l|l|}
\hline & Sum of Squares & Df & Mean Square & F & Sig. \\
\hline Between Groups & 223.333 & 2 & 111.667 & 6.637 & .003 \\
Within Groups & 706.667 & 42 & 16.825 & & \\
Total & 930.000 & 44 & & & \\
\hline
\end{tabular}

Tabel 8 Output Post Hoc Tests Multiple Comparisons

Pemahaman_Konsep_Matematika

Tukey HSD

\begin{tabular}{|c|c|c|c|c|c|c|}
\hline \multirow{2}{*}{\multicolumn{2}{|c|}{\begin{tabular}{|cc}
$(\mathrm{I})$ & $(\mathrm{J})$ \\
MODEL_PEM & MODEL_PEM \\
BELAJARAN & BELAJARAN
\end{tabular}}} & \multirow{2}{*}{$\begin{array}{l}\text { Mean } \\
\text { Difference } \\
\quad(\mathrm{I}-\mathrm{J})\end{array}$} & \multirow[b]{2}{*}{ Std. Error } & \multirow[b]{2}{*}{ Sig. } & \multicolumn{2}{|c|}{ 95\% Confidence Interval } \\
\hline & & & & & Lower Bound & Upper Bound \\
\hline \multirow[t]{2}{*}{ TAI } & PBL & -1.66667 & 1.49779 & .512 & -5.3055 & 1.9722 \\
\hline & Konvensional & $3.66667^{*}$ & 1.49779 & .048 & .0278 & 7.3055 \\
\hline \multirow[t]{2}{*}{ PBL } & TAI & 1.66667 & 1.49779 & .512 & -1.9722 & 5.3055 \\
\hline & Konvensional & $5.33333^{*}$ & 1.49779 & .003 & 1.6945 & 8.9722 \\
\hline \multirow[t]{2}{*}{ Konvensional } & TAI & $-3.66667^{*}$ & 1.49779 & .048 & -7.3055 & -.0278 \\
\hline & PBL & $-5.33333^{*}$ & 1.49779 & .003 & -8.9722 & -1.6945 \\
\hline
\end{tabular}

*. The mean difference is significant at the 0.05 level. 
Tabel 9 Homogeneous Subsets

Pemahaman_Konsep_Matematika

Tukey HSD ${ }^{\mathrm{a}}$

\begin{tabular}{|l|c|r|r|}
\hline & & \multicolumn{2}{|c|}{ Subset for alpha $=0.05$} \\
\cline { 3 - 4 } MODEL_PEMBELAJARAN & $\mathrm{N}$ & 1 & \multicolumn{1}{c|}{2} \\
\hline Konvensional & 15 & 82.6667 & \\
TAI & 15 & & 86.3333 \\
PBL & 15 & & 88.0000 \\
Sig. & & 1.000 & .512 \\
\hline
\end{tabular}

Means for groups in homogeneous subsets are displayed.

a. Uses Harmonic Mean Sample Size $=15.000$.

Tabel 8 Output Post Hoc Test digunakan untuk mengetahui pemahaman konsep mana yang memiliki perbedaan yang signifikan. Cara menganalisanya dengan melihat ada tidaknya tanda * pada kolom Mean Difference. Tanda * menunjukkan adanya perbedaan mean yang signifikan. Tabel 8 juga menunjukkan mean pemahaman konsep matematika siswa dengan model pembelajaran PBL berbeda signifikan dengan pemahaman konsep matematika siswa dengan model pembelajaran konvensional. Mean pemahaman konsep matematika siswa dengan model pembelajaran kooperatif tipe TAI berbeda signifikan dengan pemahaman konsep matematika siswa dengan model pembelajaran konvensional. Sedangkan mean pemahaman konsep matematika siswa dengan model pembelajaran kooperatif tipe TAI tidak berbeda signifikan dengan pemahaman konsep matematika siswa dengan model pembelajaran PBL. Hasil penelitian ini tidak sesuai dengan hasil penelitian Hariyati, Mardiyana dan Usodo (2013) yang menyatakan bahwa hasil belajar dengan model pembelajaran kooperatif tipe TAI lebih baik dari hasil belajar dengan PBL. Hal tersebut dikarenakan dalam penelitian ini, baik di kelas eksperimen maupun di kelas kontrok sama-sama menggunakan LKS yang berisi masalah matematika yang dikaitkan dengan kehidupan sehari-hari yang dikemas dalam soal cerita. Selain itu, siswa juga sudah terbiasa menyelesaikan soal-soal cerita. Kedua model ini juga menggunakan pendekatan pembelajaran yang sama yaitu student center.

Output pada Tabel 8 digunakan untuk mencari variabel mana yang mempunyai perbedaan mean, sedangkan output pada Tabel 9 digunakan untuk mengetahui variabel mana yang mempunyai perbedaan yang tidak terlalu signifikan. Caranya adalah dengan memperhatikan kolom Subset. Pada Tabel 9, kolom subset 1 terdapat 1 nilai dari variabel model pembelajaran konvensional. Sedangkan pada kolom subset 2 terdapat 2 nilai dari varibel model pembelajaran kooperatif tipe TAI dan PBL. Hal ini menunjukkan mean pemahaman konsep matematika siswa dengan model pembelajaran kooperatif tipe TAI dan PBL tidak memiliki perbedaan yang signifikan. Sehingga dapat simpulkan bahwa ada pengaruh pengaruh model pembelajaran kooperatif tipe TAI dan problem based 
learning (PBL) terhadap pemahanan konsep matematika siswa.

Pengaruh model pembelajaran kooperatif tipe TAI dan problem based learning (PBL) terhadap pemahanan konsep bangun ruang siswa disebabkan karena guru tidak mendominasi kegiatan pembelajaran, guru memberikan kesempatan yang seluasluasnya bagi siswa untuk terlibat aktif dan memberikan banyak kesempatan bagi siswa untuk mengembangkan konsep secara individu maupun kelompok. Siswa belajar dengan aktif berdiskusi dan kerja sama, menemukan prinsip-prinsip dalam menyelesaikan masalah. Selain itu siswa dilatih untuk dapat memecahkan masalah yang mereka hadapi dalam situasi nyata, misalnya dalam bentuk simulasi dan masalah yang memang ada di dunia nyata.

Perbedaan yang signifikan antara kelompok siswa yang mengikuti model pembelajaran kooperatif tipe TAI dan kelompok siswa yang mengikuti pembelajaran konvensional disebabkan karena perbedaan perlakuan pada langkah-langkah pembelajaran dan proses penyampaian materi (Asriningsih, Renda, dan Wibawa, 2014 dan Tristanti dan Rakhmawati, 2017). Model pembelajaran kooperatif tipe TAI merupakan model pembelajaran yang memungkinkan siswa mengalami sendiri apa yang dipelajarinya, siswa untuk menguatkan, memperluas dan menerapkan pengetahuan dan keterampilan akademik mereka dalam berbagai macam tangtangan kehidupan baik di sekolah maupun diluar sekolah. Sehingga adanya kemandiran siswa dalam mengkonstruk pemahaman terhadap konsep matematika. Sedangkan perbedaan yang signifikan antara kelompok siswa yang mengikuti PBL dan kelompok siswa yang mengikuti pembelajaran konvensional disebabkan karena PBL membantu siswa dalam mengembangkan kemampuan analisis yang meliputi mendefinisikan dan menyelesaikan masalah. Selain itu, PBL juga mengembangkan kemampuan siswa dalam mengambil keputusan saat menyelesaikan masalah (Tosun dan Taskesenligil, 2011).

\section{KESIMPULAN DAN SARAN}

Hasil penelitian menunjukkan pemahaman konsep matematika siswa dengan model pembelajaran kooperatif tipe TAI tidak berbeda signifikan dengan pemahaman konsep matematika siswa dengan model pembelajaran PBL. Pemahaman konsep matematika siswa dengan model pembelajaran kooperatif tipe TAI berbeda signifikan dengan pemahaman konsep matematika siswa dengan model pembelajaran konvensional. Pemahaman konsep matematika siswa dengan model pembelajaran PBL berbeda signifikan dengan pemahaman konsep matematika siswa dengan model pembelajaran konvensional. Sehingga dapat disimpulkan ada pengaruh pengaruh model pembelajaran kooperatif tipe TAI dan problem based learning (PBL) terhadap pemahanan konsep matematika siswa.

Karena ada pengaruh pengaruh model pembelajaran kooperatif tipe TAI dan problem based learning (PBL) terhadap pemahanan konsep matematika siswa, maka disarankan untuk mengembangkan perangkat pembelajaran dengan menggunakan model pembelajaran kooperatif tipe TAI dan problem based learning (PBL), sehingga diperoleh perangkat pembelajaran yang benar-benar valid dan lebih dapat meningkatkan keefektifan belajar siswa. 


\section{DAFTAR PUSTAKA}

Asriningsih, K., Renda, N, T., dan Wibawa, I, M, C. 2014. Pengaruh Model Pembelajaran Kooperatif Tipe Team Assisted Individualization (TAI) terhadap Hasil Belajar IPA Siswa Kelas Iv Sd Gugus V Kecamatan Banjar. Jurnal Mimbar PGSD Universitas Pendidikan Ganesha Jurusan PGSD. Vol. 2, No. 1.

Gupta, M. dan Jain, M., 2014. Gender related effects of co-operative learning strategies (STAD and TAI) on mathematics achievement. Vol 2, No.1, Hal. 53-68,.

Hariyati, E., Mardiyana dan Usodo, B. 2013. Efektivitas Model Pembelajaran Kooperatif Tipe Team Assisted Individualization (TAI) dan Problem Based Learning (PBL) Pada Prestasi Belajar Matematika Ditinjau dari Multiple Intelligences Siswa Smp Kabupaten Lampung Timur Tahun Pelajaran 2012/2013. Jurnal Elektronik Pembelajaran Matematika. Vol. 1, No. 7, Hal. 721-731.

Hudojo, H. 2001. Pengembangan Kurikulum dan Pembelajaran Matematika. JICA Universitas Negeri malang.

Johnson, D. W., Johnson, R. T., \& Stanne, M. E. 2000. Cooperative learning methods: A metaanalysis. Retrieved June 15, 2004, from Cooperative Learning Center website: http://www.cooperation.org/pages/clmethods.html.
Kurniasih, Imam \& Sani, Berlin. 2016.

Model Pembelajaran.

Yogyakarta: Kata Pena.

National Council of Teachers of Mathematics (NCTM). 2000. Principles and Standards of School Mathematics. Reston, VA: Author.

Pasani, C. F and Basil, M. 2014. Mengembangkan Karakter Tanggung Jawab Siswa Melalui Pembelajaran Matematika dengan Model Kooperatif Tipe TAI di Kelas VIII SMPN. EDU-MAT Jurnal Pendidikan Matematika. Vol. 2, No. 3, Hal. 219 - 229.

Ramlan. 2013. Meningkatkan SelfEfficacy Pada Pembelajaran Matematika Melalui Model Kooperatif Tipe Team Assisted Individualization (TAI) Pada Siswa Kelas VII-a SMP Negeri 27 Makassar. Jurnal Matematika Dan Pembelajaran (Mapan). Vol. 1, No. 1, Hal. 110-112.

Ratumanan. T.G. 2002. Belajar dan Pembelajaran. Unesa University Press. Surabaya.

Reid, J. 1992. The Effects of Cooperative Learning with Intergroup Competition on the Math Achievement of Seventh Grade Students.

Shoimin, A. 2014. Model-Model Pembelajara Inovatif. Yogyakarta: Ar- Ruzz Media.

Slavin, R. 1994. Student Motivation, Students to Excel: Incentives Cooperatives Tasks and Students' Achievements. The Elementary School Journal. Vol. 85, Hal. 53-62. 
Slavin, R., E. 1983. Team-Assisted Individualization: A Cooperative Learning Solution for Adaptive Instruction in Mathematics.

Tarim, K., dan Akdeniz, F. 2008. The effects of cooperative learning on Turkish elementary students' mathematics achievement and attitude towards mathematics using TAI and STAD methods. Educational studies in Mathematics. Vol. 67, No. 1, Hal 77-91.

Tinungki, G., M. 2015. The Role of Cooperative Learning Type Team Assisted Individualization to Improve the Students' Mathematics Communication Ability in the Subject of Probability Theory. Journal of Education and Practice. Vol. 6, No. 32, Hal. 27 - 31.

Tristanti, L.B, dan Rakhmawati, N. 2017. Efektifitas Model Pembelajaran Kooperatif Tipe TAI dalam Pembelajaran Geometri Dimensi Tiga. Edumath, Jurnal Program Studi Pendidikan Matematika STKIP PGRI Jombang. Vol. 4, No. 1, Hal 67-76.

Tosun, C., dan Taskesenligil, Y. 2011. The Effect of Problem Based Learning on Student Motivation Toward Chemistry Classes and on Learning Strategies. Journal of Turkish Sciencies Education. Vol. 9, No. 1, Hal. 104-125.

Vaughan, W. 2002. Effects of Cooperative Learning on Achievement and Attitude Among Students of Color. The Journal of Educational Research. Vol. 95. No.6, Hal. 359-364.
Xin, F. 1996. The Effects of ComputerAssisted Cooperative Learning in Mathematics in Integrated Classrooms for Students with and without Disabilities. Final Report. 